\title{
ROSARIO CASTELLANOS: LOS DERROTEROS DE LA IMPIEDAD
}

\section{ROSARIO CASTELLANOS: THE COURSES OF UNGODLINESS}

\author{
Lilia SOLÓRZANO ESQUEDA Y \\ Mariana del Carmen ESTRADA GAYTÁN
}

Authors/ Autoras:

Lilia Solórzano Esqueda

Universidad de Guanajuato

Guanajuato, México

liliasolorzano@hotmail.com

https://orcid.org/0000-0001-5483-8288

Mariana del Carmen Estrada Gaytán Universidad de Guanajuato

Guanajuato, México

mariana_estrada5@hotmail.com

https://orcid.org/0000-0002-9182-9804

Submitted / Recibido: 15/01/2020

Accepted / Aceptado: 13/04/2020

To cite this article / Para citar este artículo: Solórzano Esqueda, Lilia y Estrada Gaytán, Mariana del Carmen. «Rosario Castellanos: los derroteros de la impiedad». In Feminismo/s, 36 (December 2020):

231-253, https://doi.org/10.14198/

fem.2020.36.10

Licence / Licencia:

This work is licensed under a Creative Commons Attribution 4.0 International.

\section{(c) (1)}

(C) Lilia Solórzano Esqueda y

Mariana del Carmen Estrada Gaytán

\section{Resumen}

Desde sus primeros poemarios y en su investigación de tesis de maestría en filosofía, Rosario Castellanos mostró una constante: su preocupación por indagar sobre la imagen conceptual y la condición de la mujer en un mundo mayoritariamente pensado y dirigido por hombres. En su poemario En la tierra de en medio (1972), apuntala esa constante. El poema «Bella dama sin piedad» abre en una reelaboración del antiguo tópico de la muerte con forma de lo femenino; pero en el libro va adquiriendo nuevas interpretaciones, combinándose con las actitudes que presenta la mujer frente a sus diversas circunstancias. Este texto propone pistas sobre cómo la poeta va construyendo y resignificando, sin piedad, ese territorio de en medio que aparentemente no tiene confines y que habita la mujer, desde las propias coordenadas de pensamiento de la autora mexicana.

Palabras clave: Rosario Castellanos; poesía mexicana; cultura femenina; Bella dama sin piedad; impiedad. 


\begin{abstract}
From her early poems as well as her thesis research of master's degree in philosophy, Rosario Castellanos showed a constant: their concern and interest in investigating the conceptual image and status of women in a world largely led by men. In her mature poetry En la tierra de en medio (1972), she points to this same constant. It opens with the poem «Bella dama sin piedad» in a reworking of the ancient topic of death in the form of the feminine; but in the book it is acquiring new interpretations, combined with the attitudes women posing in front of their different circumstances. In this text it is proposed to give clues about how the poet is constructing and resignificing, effectively without mercy, that middle ground that apparently has no boundaries and that inhabits the woman, from the Mexican author's own theory.
\end{abstract}

Keywords: Rosario Castellanos; Mexican poetry; female culture; Beautiful lady without mercy; ungodliness.

\title{
1. ¿DE QUÉ HABLA ROSARIO CASTELLANOS CUANDO HABLA DE «DAMA SIN PIEDAD»?
}

«Bella dama sin piedad» es el poema que abre En la tierra de en medio, de Rosario Castellanos. Por el título, vemos ya que la autora pone en escena un diálogo con aquel viejo tópico de la belle dame sans merci, haciendo un llamado a la tradición francesa del medioevo con el poema de Alain Chartier, y conjura el noctium phantasmata del gran poema homónimo de John Keats.

En términos generales, el mito de la belle dame sans merci se funda en la configuración de una imagen femenil que, como las sirenas, seduce al hombre mediante su belleza. Su fatalidad radica en el engaño y las apariencias: la bella dama promete amor, pero no tiene cuerpo; seduce para llevarse las riquezas del amante, pero en su vertiginosidad, no da nada a cambio. La bella dama es temible y fascinante, atractiva y repelente a la vez; es despiadada porque en realidad es la muerte.

Frente a la obra de Chartier (en la que se lleva a cabo un contacto directo a través de un diálogo entre la dama y su amado), el mito de la bella dama sin piedad que eclosiona en la obra de Keats se centra mucho más en describir hacia dónde lleva una falsa ilusión. En el poema del escritor inglés, un caballero solitario canta sus desdichas: luego de haber sido seducido y abandonado por la mujer furtiva, el caballero, consciente ya de haber sufrido un rapto

Feminismo/s 36, December 2020, 231-253 
fatídico, canta entonces desengañado sus desdichas por haber sido víctima de sus falsas ilusiones. En esta línea se puede trazar un parangón con el poema de Rosario Castellanos, donde la voz enuncia a la bella dama a través de su ausencia, mediante el encuentro «real» nunca suscitado. A la vez, denota su presencia a través de la evocación constante:

Se deslizaba por las galerías.

No la vi. Llegué tarde, como todos, y alcancé nada más la lentitud

púrpura de la cauda; la atmósfera vibrante

de aria recién cantada. (Poesía no eres tú 289)

El poema se inicia evocando a la figura femenil ausente. Continúan las estrofas describiendo a la dama por lo que es y lo que no; lo que la voz lírica conoce de esa presencia ausente a través, únicamente, de la evocación cantada en múltiples formas. Así, al avanzar por las estrofas, el sujeto lírico que canta, se habla para sí, como en un gesto de reflexión en voz alta: «Sueña, no está. Imagina, no es. Recuerda, se sustituye. Inventa, se anticipa, dice adiós o mañana» (289) pero nunca hoy, nunca presente. Y entre los versos del poema nos preguntamos: ¿quién es el buscador que persigue la cauda púrpura? ¿quién es víctima de la ilusión que anda tras la necesidad de evocar a una figura femenil encubierta?

Se ha dicho antes que el poema de Castellanos está más cerca de dialogar con el poema de Keats, pero es importante resaltar una diferencia: en el texto de la escritora no se manifiesta expresamente una imagen femenil fatal y enajenante que se desdoble en la promesa del amor sin cuerpo y que se lleve todo sin dar nada a cambio; no hay una proyección de la femme fatale (al menos no una proyección explícita), más bien, el poema tiene por centro resaltar la vertiginosidad de aquella dama y de lo que esta siembra dentro de sí.

Alegóricamente, la huella morada que deja la dama a través de su cauda -de ese ritmo con el que se intuye ya una suerte de seducción- recuerda a la simbología remitida en los libros de caballería. Durante el medioevo, este color heráldico era identificado en su conjunto con llamas «purificadoras», simbolizando así el paso de una expiación de culpas en el purgatorio a la representación de la ansiedad amorosa. En suma, las alegorías asignadas a los colores litúrgicos dieron al morado connotaciones de desasosiego, de 
sufrimiento o de desesperación; aspecto que después derivó en el dolor y en la penitencia propios de los tiempos preparatorios de adviento y de cuaresma. Este paréntesis abierto a propósito del color puede llevarnos a pensar si la cauda púrpura es acaso una premonición sobre alguna penitencia; a pensar si En la tierra de en medio se viste de morado, como una especie de poemario punitivo en ese terreno que no consigue ser absolutamente ni lo uno ni lo otro: ni la mujer que responde a su prototipo histórico-cultural, ni la rompedora de imágenes y mitos. Tal vez porque los absolutos no son humanos, y la mujer -lo mismo que el hombre- es una construcción constante.

«Bella dama sin piedad», es una apertura del mito y es también la puerta de acceso hacia la muerte, que no se apiada de la vida pero que la ronda y la seduce. En cuanto el lector abre la página y se dispone a leer En la tierra de en medio, enlazamos de inmediato con esa otra "Advertencia a todo el que llega», obra integrada en Otros poemas fuera de colección; aquí comienza por decir: «No me toques el brazo izquierdo. / Duele de tanta cicatriz. Dicen que fue un intento de suicidio / pero yo no quería más que dormir / profunda, largamente como duerme la mujer que es feliz.» (Poesía no eres tú 334). Lo cual es terrible, porque aunque no es propiamente una tierra de en medio, la tentativa de suicidio sí habla del desajuste con la vida y el anhelo por la muerte para conseguir un estado de bienestar. Eso significa un no estado, o estados cifrados por la provisionalidad.

Desde la Antigüedad clásica, en la Edad Media, en la tradición romántica y en las corrientes decadentistas, la belleza deslumbrante de la figura femenina llegó a asociarse con motivos de temor y desconfianza. Como encarnación del mal, el cuerpo de la mujer, así como todo cuanto la embellece, se asocia con un abismo de perdición. Durante este tiempo se confirió especial relieve a la mujer que hace de su hermosura el medio para el rapto. Entonces, la belleza del mal -como la prefigura Charles Baudelaire en Las flores del mal, pero tal vez más crudamente en Los despojos donde incluyó poemas que habían sido sancionados en sus flores malditas-, condensó esa asociación belleza-mal en la femme fatale, en la vampiresa que, bajo diferentes retratos y nombres de la bella despiadada, llevaba consigo el encanto y la tragedia por conducir al hombre a la anarquía de los sentidos y al caos, a la muerte.

A partir del siglo xx, las imágenes aterradoras de la belleza y las sentencias acerca de los encantos de la mujer adquieren gradualmente un cambio

Feminismo/s 36, December 2020, 231-253 
profundo; sucede un eclipse de la mitología de la mujer fatal. Es verdad que en el poema de Castellanos la figura femenil se presenta igual de seductora y vertiginosa, pero la diferencia que abre brecha entre la propuesta de la escritora frente a la línea constante del antiguo mito se hace evidente al continuar las páginas del poemario: la dama impiadosa se encarga de seducir a otra mujer que trae consigo un espejo de mil rostros, lo sabemos principalmente por los deícticos que dan carácter a la voz lírica femenil. De aquí nace una propuesta reflexiva sobre la condición de la mujer a partir de la reelaboración del viejo tópico. Lo que a Rosario Castellanos le interesa de la belle dame sans merci es esencialmente lo que hay detrás de la intención de evocarla, de tratar de alcanzar siempre a esa figura mortuoria.

La imagen de la Melussina de Castellanos se descubre conforme avanzan las páginas del poemario. Se devela la causa de un encanto fiero, despiadado y se fragua la presencia prometida y tantas veces evocada: la dama es la Devoradora, «el Mal, con Mayúscula» (Obras II. Poesía, teatro y ensayo 193), la antagonista, la ausente. Y en todo este discurso se erige -detrás de esta invitación al desencanto- la necesidad de repensar social y simbólicamente la condición de la mujer.

Nos preguntamos entonces cuál es la causa de que aquella voz femenil persiga siempre a la bella despiadada que está presente en todos los poemas, ya en forma alegórica a través de un pensamiento (con nociones suicidas, tácitas o no), ya mediante la enunciación explícita de la muerte. Indiscutiblemente articulamos esta pregunta con el tono agudo y desolador que ronda en los poemas de En la tierra de en medio y asociamos entonces la persecución a la idea de la muerte con el vacío eterno. Hay un vínculo entre la mujer de vestimenta púrpura y la noción espacial de algo hueco y ausente; del espacio que paradójicamente resulta habitable y al alcance de la mujer asediada por tantos arquetipos y falsas estampas sobre lo que es la libertad.

La bella dama sin piedad está representada en diferentes contextos y circunstancias; coyuntura vinculada con una situación de desdicha. Basta tan sólo hacer un repaso de los títulos: «Válium 10», «Elegía», «Mala fe», «La nostalgia». Todos los poemas ponen en el centro a la mujer infeliz, a la que sufre y se engaña a sí misma sobre haber encontrado una falsa salida; todos pintan el hilo púrpura que une la cauda cantada por la muerte. 
«Human kind cannot bear very much reality», dice el pájaro al final de la primera sección de los Cuatro cuartetos de T. S. Eliot. Esta es la cita que utiliza Castellanos como epígrafe para su poemario (Poesía no eres tú 288), haciéndonos saber que no hay posibilidad de recurrir a la capacidad ilimitada de los seres humanos para ignorar lo que no se quiere conocer: el dolor, la desdicha y la infelicidad como circunstancias en las que se vive. Ante esta premisa, nos preguntaríamos: ¿para qué ignorarlo? Al contrario, la poeta busca hablar desde su hacer escritural consciente, de las máscaras sociales que hacen a la mujer henchida de infelicidad.

Se sabe desde las primeras líneas del poemario que la autora también hablará del hacer poético desde su experiencia escritural. Traemos de vuelta los primeros versos que hacen de puerta-invitación a En la tierra de en medio: «[... ] alcancé nada más la lentitud / púrpura de la cauda; la atmósfera vibrante / de aria recién cantada» (289). La cauda y el aria cantadas en una habitación púrpura estrechan el vínculo entre la dama despiadada y el canto, entre la muerte y la poesía. Rosario Castellanos relaciona su capacidad de escribir con su capacidad del bien morir. Entonces la segunda característica de la bella dama sin piedad (la faceta seductora) desvela su otra cara: la de su relación con la experiencia escritural. Para comprender esto, resulta preciso no perder de vista que en los poemas, la seducción conduce siempre la levedad o gravedad de la presencia de la muerte. Inés Zaldívar, en su artículo «Escritura y maternidad en un poemario de Rosario Castellanos», vio también en la autora mexicana cómo «el quehacer literario fue el eje que la estructuró, le dio un sentido vital profundo y la definió como persona. Su vida giró en torno a lo que podría llamar una pulsión creativa, a la imperiosa necesidad de ser fiel a la palabra» (16). La escritura le da fuerza y la constituye como ser integral en un mundo por varios flancos hostil. Una de las constantes que corre transversalmente por su obra es el ejercicio del pensamiento. Por tanto, podemos ir vislumbrando que lo despiadado en una mujer, según este enfoque de la escritora mexicana y a contracorriente de lo que marca cierta tradición, es encontrar uno de los rostros más productivos y auténticos mediante la reflexión en la escritura.

«Elegía», «Pequeña crónica», «Entrevista de prensa»y «Post-scriptum» muestran cómo la literatura está pensando y preguntándose sobre el hacer escritural desde sí misma. La literatura empieza en el momento en que ella

Feminismo/s 36, December 2020, 231-253 
misma es pregunta. En «Poesía no eres tú» destaca una simbólica subversión frente al famoso verso becqueriano, al tiempo de proponer la autoafirmación y el resurgimiento a partir de la «mentira» a que nos ha sometido la historia construida por el discurso varonil. Dice Castellanos:

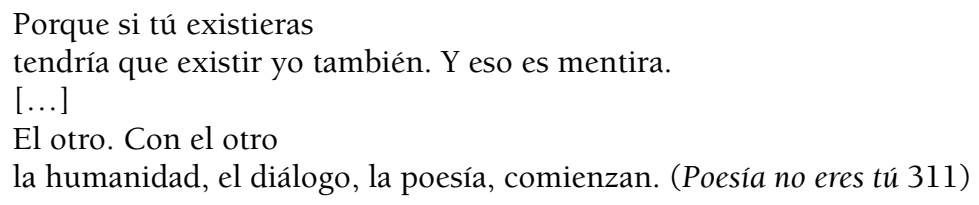

Porque si tú existieras

tendría que existir yo también. Y eso es mentira.

[...]

El otro. Con el otro

la humanidad, el diálogo, la poesía, comienzan. (Poesía no eres tú 311)

La voz lírica de este último poema se pone a prueba a sí misma como una nulidad, como una nada que trabaja, y que, tras haber escrito todo un poemario que está a punto de cerrar, prueba su obra como algo que desaparece (de ahí la reversión a la premisa de la rima becqueriana XXI), pero que vuelve a comenzar con un sentido más comunitario, el del diálogo que se abre con todos, conjuntamente. Sólo así habrá poesía. La Castellanos poeta recurre a su hacer escritural como una operación que reconoce íntimamente suya, para luego volverse consciente de su condición como mujer en México y en el mundo, donde la moral normalmente nos construye como lastre.

Cuando la poesía de la autora chiapaneca apela a la escritura (ya sea a través de los títulos de sus poemas, mediante la disposición de sus textos o a través de esa cauda purpúrea que nos abre la puerta), habla de una conciencia escritural, incluso al expresarse sobre la poesía que no es, de la que no vive. Es a partir de esa conciencia que la autora se niega a sí, para de algún modo asumir su no existencia -y connotar la muerte- como el único espacio de enmienda personal y comunitaria. Entonces, esa persecución a la dama lleva detrás la presunción de un devenir personal. Quién si no la escritora para mirar el espejo que contiene mil rostros y que refleja siempre en su pupila una cara furtiva.

La obra de Castellanos corre, sin dudar, a quitarle el velo a las variadas máscaras culturales que construyen una falsa idea de la mujer, de ahí el constante recurrir a la figura femenil bajo diferentes circunstancias encerradas todas ellas dentro de un marco de desdicha: «La unidad de los libros -dice Elena Poniatowska- la constituye la persistencia recurrente de ciertas figuras; la niña desvalida, la adolescente encerrada, la solterona vencida, la casada defraudada. No hay opción. Dentro de esos marcos establecidos, sí, la fuga, 
la locura, la muerte» (Poniatowska en Castellanos, Meditación en el umbral. Antología poética 14). Todas estas facetas, que bien podrían entrar en el índice de El segundo sexo de Simone de Beauvoir, nos hacen preguntarnos (por su semejanza) si existe entre ellas alguna diferencia. La extranjera, la solterona, la viuda... todas devienen de un mismo hoyo cavado por la imposición social. «Las primeras como las otras alternativas no son propiamente cauces de vida sino formas de muerte» (14). ¿Este es acaso el motor de seducción de la bella dama despiadada?

En el momento en que la voz poética alude a la enamorada desdichada; a la infeliz engañada; a la ninfómana abatida; a la casada traicionada por su propio sueño; a la madre exhumada, alude a la danza de la muerte (de su propia muerte) dentro de esa tierra de en medio que se torna un «no lugar». Y entonces, como si Castellanos actualizara el tópico del ubi sunt, se recuerda el paradero de todas esas máscaras que resultan importantes de enunciar aunque se vuelvan una lista infinita, pues finalmente la enunciación abre un marco reflexivo sobre la imagen y la condición de la mujer en un mundo mayoritariamente pensado y dirigido por hombres. He ahí el motivo de la recurrente evocación a la Belle dame sans merci. Las tantas condiciones que derivan en una sola imagen de la mujer desdichada la asedian únicamente en la línea que lleva por esencia una atmósfera mortífera. Ahora bien, ¿qué móvil está detrás del sentido evasivo que tiene la bella dama sin piedad?

Cuando Castellanos escribe la sentencia «Poesía no eres tú», confirma que gracias a ésta, la poeta es poeta: de ella obtiene su existencia. La escritora ha hecho la metáfora y la metáfora la ha hecho a ella. «Poesía no eres tú» tiene tal sentido de realidad y existencia que convierte a quien lo ha escrito, paradójica y redundantemente -por contradictorio que esto suene-, en poeta; y esto es así porque la autora no solo es vivencialmente su frase, su metáfora, sino porque es la metáfora de otros hombres y mujeres capaces de leerla; es, en suma, una frase universal. Todo esto se condensa en el cierre del poema: «El otro. Con el otro / la humanidad, el diálogo, la poesía, comienzan.» (Poesía no eres tú 311).

Aquí entra en juego la dimensión de la figura femenil que se identifica como autora, y que, a decir verdad, se aleja de una connotación de lo desolador e infeliz que desprendían los otros tantos rostros de la mujer. En esta dimensión, ya lo hemos visto, la figura de la poeta solo existe en su obra,

Feminismo/s 36, December 2020, 231-253 
pero la obra solo existe cuando es esa realidad pública, hecha y desecha por el choque con lo otro, con los otros. El problema, si es que así puede llamársele, radica en la inexistencia armónica con el otro. Cuando no se reconoce un oído que escuche, que contemple y que comprenda la voz femenil que se alza en tono quebrantado, la existencia se anula. Entonces la poesía, como la mujer, se encuentran bailando entre la muerte. La poesía es, sin llegar a ser plenamente.

\section{ABRIR LAS CERRADAS GALERÍAS}

Con las poderosas armas del pensamiento y la escritura, Castellanos puede figurar unos rostros infinitamente más interesantes detrás de las múltiples máscaras tradicionales de la mujer. La dama no piadosa, la impía, es contraparte de aquella que históricamente había sido relegada a ayudante en todo lo concerniente a los oficios religiosos, tarea extrapolada a los oficios del hogar. La dama que para ser tal debía cumplir el papel sacrosanto de ángel del hogar, sostén de la familia, bálsamo en los problemas, siempre presta para otorgar apoyo, servicial y bondadosa, humilde, talentosa pero no tanto, siempre presentable y hermosa.

La piedad ${ }^{1}$ pasó de ser misericordia a tomarse el lugar de una afección que es casi una banalidad: la cualidad por excelencia reconocida, por un grupo social determinado, del conjunto que constituye la imagen de una «buena mujer». La misericordia en su origen era un sentimiento profundamente inclinado hacia el semejante, ahí donde el corazón tenía un lugar principal, y se significaba por darle consuelo a ese otro que por una u otra razón se había vuelto enemigo del amor.

Aristóteles ya define la piedad como una virtud, una «posesión o hábito del alma» (Magna Moralia 143) ubicada en la parte irracional del alma (145).

1. Posiblemente sea en Esquilo donde se pueda rastrear una de las primeras apariciones de la piedad en la literatura: el perdón de Orestes por parte del Areópago para que las Erinias pongan punto final a su persecución. En Sófocles se plantea la redención de Edipo por parte de la acción de la justicia compensatoria de Diké, y también de la piedad de Antígona que se ofrece en sacrificio a cambio de otorgar un funeral digno a su hermano Polínices. En el diálogo platónico Eutifrón se ofrece el significado más antiguo del término «piedad»: «Es, ciertamente, pío lo que agrada a los dioses, y lo que no les agrada es impío.» (Diálogos 226)

Feminismo/s 36, December 2020, 231-253 
Sentencia que «si vivimos de acuerdo con las virtudes seremos felices y poseeremos el bien supremo» (143). El filósofo griego radica en el alma a las «pasiones, facultades y hábitos» (147) y dentro de las pasiones enumera a la piedad. Pero, según su teoría, el ser piadoso no garantiza ser virtuoso porque se puede tener esta pasión o sentimiento en exceso o en defecto. Lo virtuoso, dirá el Estagirita, será poder encontrar y permanecer en el justo medio, que es lo que conviene a un «hombre de bien» (150), en alma y en cuerpo.

Y aunque en Aristóteles, en la puesta en acto de las pasiones, se realiza un ejercicio de elección que parece tender siempre hacia lo mejor porque lógicamente nadie quiere para sí lo malo, esta elección no aplica en una costumbre de piedad sancionada por siglos de construcción cultural netamente patriarcal. Este tipo de elección no emerge desde la libre voluntad de la mujer porque no se enuncia desde la autodeterminación de ella como sujeto independiente y reflexivo, sino que le viene determinada desde fuera. En la sociedad actual revisada por Castellanos, se ha querido proponer como noble un tipo de piedad que somete o sujeta a las mujeres y no guarda relación alguna con aquella virtud clásica antigua de amar lo sagrado, un sentimiento que disimula un estado de cosas extraño por completo a la construcción de un sujeto tendiente hacia el bien.

En la civilización romana, el pius compendiaba una serie de bondades, según puede comprobarse en la configuración que Virgilio destina a su héroe Eneas, al que llama en la Eneida «pietate gravem ac meritis», o sea, «varón grave con ganados méritos de virtud y bondad» (205); o bien «pius Aeneas», «el piadoso Eneas» (209), según la traducción de Aurelio Espinoza. Lo piadoso en Eneas conforma su ethos de gran varón fundador de Roma. Este concepto de piedad no es el que se ha filtrado hacia la mujer en nuestras sociedades contemporáneas.

Cuando Marcel Schwob reflexiona a propósito de la piedad, en El terror y la piedad, nos lleva a imaginar el ritmo de la sociedad como un péndulo donde la vida individual tiene como contrapeso y continuidad las vidas de los otros, la comunidad. Lo expresa en términos más espirituales que materiales cuando afirma que «el alma va de un extremo al otro, de la expansión de su propia vida a la expansión de la vida de todos» (27-28), y en este movimiento experimenta terrores ligados a lo arquetípico y primordial que le inducen al sentimiento de la compasión de sí y por el otro. Identifica compasión con

Feminismo/s 36, December 2020, 231-253 
piedad, padecer con el sentimiento del otro, recordando la conceptualización de la tragedia griega por parte de Aristóteles. Aquí «compasión y sacrificio» (32) son la dualidad que se compartía en el escenario para finalmente incidir en el efecto catártico del público. Interesa destacar en este enfoque cómo la noción de sacrificio ha ido continuamente aparejada a la noción de piedad. Alguien piadoso siempre mantendrá una reserva de sacrificialidad. En la historia de la humanidad normalmente los varones piadosos han sido los sacerdotes o santos, o los héroes que se privan de algo con miras a conseguir un bien que excede su individualidad. Por contraparte, de la mujer se espera esta ablación de la voluntad de manera casi natural, porque se ha normalizado que en ello estribe el valor de una mujer virtuosa. Un sentido bastante lejano de aquel padecere clásico de la antigüedad griega.

Louis Althusser mantiene con Rousseau una interesante discusión a propósito de la piedad. Para el filósofo ilustrado -sostiene Althusser- la piedad era un sentimiento expresado en el estado de más pura naturaleza en los hombres; así que en ocasión del «desarrollo de la razón», este sentimiento se vio «asfixiado» (308). Para Rousseau, la piedad es la más importante de las virtudes sociales, de ella emanan las restantes, es casi el basamento moral de la vida comunitaria. Althusser encuentra que Rousseau funda la moralidad en la piedad, al tiempo de «identificar la moralidad con el sufrimiento» (309). Porque Rousseau pensaba que el que sufre más, el más desvalido, es el pobre. Se tiene piedad de alguien que sufre, se le reconoce y compadece en su dolor, que en ocasiones se vuelve nuestro también. En este escenario puede revelarse de igual forma el desequilibrio: el poderoso y el débil. El que consuela y el que sufre. Cuando el estado de naturaleza pase a estado regulado por la ley se hará más profunda la separación, y la piedad será únicamente un sentimiento que estorbe o que se quede entre los débiles en aquel estado de naturaleza ya superado por el grupo que detenta el poder y que finalmente crea las regulaciones sociales.

Para María Zambrano, todo lo que es factible de ser pensado y razonado, tuvo por principio de cuentas que ser sentido «el signo supremo de veracidad [...] ha sido siempre el sentir» (65), afirma en «Para una historia de la Piedad». La filósofa coloca al sentimiento como fundamento de todo lo humano. Y de entre todos los sentimientos, el de la piedad le resulta el primordial; es, dice «quizá, el sentimiento inicial, el más amplio y hondo; 
algo así como la patria de todos los demás», «la prehistoria de todos los sentimientos positivos» (66). Y sintetiza: «Piedad es saber tratar con lo diferente, con lo que es radicalmente otro que nosotros» (68). La filósofa española, en su especial combinación y recreación de la tradición clásica griega con la cristiana, logra ponernos delante o revelarnos un nuevo sentido de la piedad, inclinado a dialogar y pensar con aquello otro que me saca de mi mismidad. Si fuera consensuado y habitual este sentido de la piedad, sería un espacio muy fértil para la concordia y un nuevo hacer comunitario. Sin embargo, nuestra realidad no se comporta de esta manera. Es otro el derrotero de este sentimiento y es otra su función convencional.

Miguel Ángel escogió la piedad de entre todos los sentimientos para mostrarnos -y en esa muestra eternizar- un momento sublime: el dolor inenarrable que padece la madre cuando le matan un hijo, al tiempo de compartirnos la inmensa ternura de ese corazón de madre por el desventurado hijo, y en ese mismo acto movernos a nosotros hacia la piedad. En esta escultura se queda fijada en la memoria colectiva, en el inconsciente, esa estampa cultural y social de la madre por excelencia. Nadie podría atreverse a desacralizar ese icono. Y no es que se niegue el dolor de una madre cuando le matan al hijo. Eso debe ser tremendo. Es que por ese camino, el símbolo ya difícilmente permitirá alguna otra opción de lectura para la figura de la «madre». A partir del simbolismo cristiano, la madre siempre deberá ser la que sufre y se desvive por los demás. Esa será la verdad inapelable, el código moral.

En las sociedades occidentales y de forma más recalcitrante en las latinoamericanas, con una estación violenta en la mexicana, la mujer ha sido confinada a papeles secundarios, cuando no invisibles. La misericordia que Castellanos ve en la mujer tradicional está más emparentada con la abnegación. Una renuncia de lo íntimo: los deseos, los afectos, los intereses propios cedidos en favor de alguien más. Siempre existirá un otro que se anteponga. En palabras de María Silvina Persino: «La maternidad es, según Castellanos, la única forma de redención que la mujer encuentra -o cree encontrar- en la sociedad patriarcal.» (10). Analiza detenidamente cómo la abnegación de la maternidad en la obra El eterno femenino de Castellanos se convierte en la mejor aliada del statu quo, al tiempo que irónicamente actúa como escudo y defensa para intentar sacar un poco de provecho en esa área de confinamiento a que se ha reducido la existencia de la mujer. Mediante la fuerza

Feminismo/s 36, December 2020, 231-253 
«corrosiva» (13) de la ironía como recurso narrativo, Persino destaca en esta obra de la escritora mexicana que «al insistirse en la parte de responsabilidad que corresponde a las mujeres en la perpetuación de la cultura patriarcal, se sugiere que la llave para el cambio no reside necesariamente en los hombres, sino en las mismas mujeres.» (13).

Durante cientos de años se le ofreció a la mujer, como un gentil gesto, una benevolencia que, bien mirado, parecería malevolencia. Una suerte de condescendencia amable por su escaso discernimiento debido a cuestiones de fisiología craneal y por tanto mental, o de una deficiencia de espíritu, según una serie de filósofos, sociólogos y psiquiatras de apellido alemán que cita Castellanos en su tesis de maestría Sobre cultura femenina (1950) y después en su libro de ensayos Mujer que sabe latín...(1973), y que van desde Schopenhauer a Weininger, Simmel, Moebius o Rudinger. En Sobre cultura femenina, al intentar una somera revisión histórica de los distintos tratamientos sobre el asunto, la poeta y ensayista se mofa un poco de los intentos de seriedad de los ilustres caballeros citados líneas arriba y remata su repaso con una humorada:

San Pablo no necesitó de tantos rodeos para declarar que la mujer es «naturalmente animal enfermo» ni Santo Tomás para conceder que es apenas un varón mutilado. Pero después de todo, dice Luis Vives en la mujer nadie busca elocuencia ni bien hablar, grandes primores de ingenio ni administración de ciudades, memoria o liberalidad; la sola cosa que se requiere en ella es, entre los cristianos, la castidad. (Entre los gentiles se le pedía más bien que fuera fecunda o placentera). (75)

¿Cuáles son las distintas imágenes que Castellanos selecciona para hablarnos de la que no tiene piedad? ¿Quién sería aquella mujer que no tendría piedad? La realidad aplasta con un peso enorme a la mujer, con una losa muy difícil de soportar

desde que nace una mujer la educación trabaja sobre el material dado para adaptarlo a su destino y convertirlo en un ente moralmente aceptable, es decir, socialmente útil. Así se le despoja de la espontaneidad para actuar; se le prohíbe la iniciativa de decidir; se le enseña a obedecer los mandamientos de una ética que le es absolutamente ajena y que no tiene más justificación ni fundamentación que la de servir a los intereses, a los propósitos y a los fines de los demás. (Sobre cultura femenina 14) 
Las diversas máscaras que presenta Castellanos en su último poemario vienen a ser otras tantas formas de advertir la muerte de un prototipo de mujer encasillada en esos cartabones. Es necesario buscar y engendrar otras realidades que no constituyan un peso, que no asfixien la vida sino que propicien la germinación. Romper los espejos que nos devuelven falsas ideas o imágenes deformadas. Hay que buscar la consistencia verdadera, o por lo menos asegurarse de que se haya realizado una elección. Elegirse a sí misma por encima de los prejuicios y juicios, personales y ajenos. El concepto «elección» aquí no es tan inofensivo. Se trae a colación porque es la propia poeta quien lo selecciona, y nos atrevemos a apuntar que en esta estrategia discursiva es el pensamiento de Kierkegaard (O lo uno o lo otro. Un fragmento de vida, vol. II) quien asoma; por esto mismo, entre líneas Castellanos nos ha puesto enfrente la discusión de un problema moral. Para el filósofo danés, la base de la construcción del individuo en sí mismo y en su convivencia con los demás para conformar la sociedad descansa en una vida ética: vivir la existencia mediante el bien o teniendo el bien como objetivo. Es decir, las consideraciones kierkegaardianas se refieren a cómo debe conducirse la persona individual en un sentido descriptivo: cómo se desarrolla su vida práctica en sus sociedades relacionales diarias y concretas; y también en un sentido prescriptivo: cómo se toma en cuenta el deber ético para la construcción de un bien general. La «elección» del individuo tiene que ver con la autonomía y con la responsabilidad: es libre de tomar decisiones que lo conforman, pero que finalmente se mueven en un marco mayor de responsabilidad social. El individuo se construye a sí mismo y en esa misma medida edifica lo que le rodea. Se «elige» en la selección que realiza con lo exterior. Lo exterior se vuelve parte de lo privado y viceversa. Uno elige amigos, profesión, pareja, todo este mundo individual y personalísimo que después (y más bien, al mismo tiempo) se confronta y ante-pone frente al mundo moral co-construido en comunidad. Somos, con mucho, el resultado de aquello con lo que nos relacionamos, con lo que co-participamos. Eso de más allá, con esto que yo pongo de mi individualidad, es mi mundo y es el mundo. Aunque «mi» individualidad es en buena parte co-responsabilidad social.

En ciertas ocasiones podemos ver una Castellanos iracunda instigándonos a «arrojar la fama para que hocen los cerdos» (Mujer que sabe latín... 20) en alusión clara a despojarnos de una vez de ese nudo de mentiras sobre el cual

Feminismo/s 36, December 2020, 231-253 
se ha montado un supuesto deber ser femenino. La frase reelabora el desdeñoso refrán que critica el contrasentido de lanzar delicadas margaritas a esos animales de granja que normalmente vemos regodearse en el lodo. Parece decir: que hablen, ¿qué nos puede importar? ¿Qué nos puede dañar? Nos daña mucho más la ignorancia y el sometimiento. Castellanos fustiga contra todo ese enredo histórico de mojigatería, de obligaciones y confinamientos severos, como si la condición de mujer fuera por sí un defecto o un acto criminal. Cierto, ya hemos avanzado un poco en la sociedad mexicana, pero solo para caer ahora en una escalada de violencia y asesinato que haría palidecer los cometidos por cualquier feminicida de cualquier siglo.

La dama sin piedad de Castellanos sería la que niega, o más bien quiere exhibir y destruir, esta serie de máscaras impuestas desde fuera a manera de ceñido corsé, que la asfixia y la empuja al desconsuelo y la pesadumbre, una tristeza tan insondable que muchas veces termina en lo que Sartre figuró como situación límite «por su desgarradora densidad metafísica» (Castellanos, Mujer que sabe latín... 19), el suicidio, por ejemplo; o en los casos positivos, la fuerza suficiente para liberarse de esos moldes. Nuevamente expresa la Castellanos ensayista:

Con una fuerza a la que no doblega ninguna coerción; con una terquedad a la que no convence ningún alegato; con una persistencia que no disminuye ante ningún fracaso, la mujer rompe los modelos que la sociedad le propone y le impone para alcanzar su imagen auténtica y consumarse $-\mathrm{y}$ consumirse- en ella.

Para elegirse a sí misma y preferirse por encima de lo demás. (Mujer que sabe latín... 19)

Las viejas costumbres que todavía en ciertos ámbitos se reproducen no son sino pantomimas, «gesticulaciones» con mucho de vacío, como el que la sociedad matrimonial sea el único modo de convivencia entre dos que posiblemente comenzaron queriéndose y han terminado odiándose; el que estas asociaciones deban constituirse por hombre y mujer; el que la iglesia católica se siga erigiendo como la única salvadora; el que se esconda el estupro, la violación de menores y de mayores al interior de una familia o de la iglesia, porque ¿qué dirá la gente si se sabe que el primo, el tío, el padre o sus pares femeninos, o el cura han cometido abuso? ¿Dónde quedará la reputación? El cuento como relato eclesiástico elevado a valor moral de la necesarísima 
virginidad-castidad hasta llegar al matrimonio, dupla mal entendida que durante siglos ha acompañado la represión y el castigo, todo esto son escenas repetidas una y otra vez bajo la máscara de costumbres heredadas que adquieren prestigio porque van alimentando una «tradición» también malentendida. Bajo este condicionamiento, la tradición sería un yugo que hay que llevar a cuestas pésele a quien le pese, sin crítica, sin responsabilidad individualidad y social, una moral que no se construye como signo de la contemporaneidad sino como lastre, que socava la libertad de decidir lo que se quiere ser.

Pensar qué queremos ser. Ese es el quid de toda la cuestión. La mujer no lo ha considerado a conciencia, a decir de Castellanos, por todo este andamiaje cultural que tira de ella en sentido contrario a la construcción en libertad y confirmación de una personalidad ${ }^{2}$. Tal vez a estas alturas de la segunda década del siglo XXI el panorama sea otro. En el tiempo que le tocó vivir a la poeta había que remar muy duro a contracorriente, ser constante y darse de topes contra muros todos los días. Datos estadísticos: ella fue una de las primeras estudiantes de filosofía con grado de maestría en México, pionera en la diplomacia nacional ${ }^{3}$, una de las escasas mujeres embajadoras, y también de las primeras escritoras mexicanas apoyadas por la Fundación Rockefeller. Marta Lamas no duda en sumarse a la afirmación de Poniatowska en el sentido de que Castellanos «establece el punto de partida intelectual de la liberación de las mujeres en México» (Poniatowska en Lamas 36).

La poeta nos invita a abandonar todo dogma que no pueda resistir la criba de la risa, a que pasemos la vida cotidiana bajo la lupa, y entonces, posiblemente, caeremos en la cuenta de que muchos de nuestros supuestos pilares morales no son sino gesticulaciones «ridículas», «obsoletas», «cursis» e «imbéciles» (Mujer que sabe latín...) que deberíamos conjurar con la risa. Reírnos de nosotros y lo que hemos elevado con muy poco ingenio e inteligencia a un pedestal obsoleto.

2. Es interesante cómo Yanina Ávila Gónzález recupera el concepto de performance tal como lo percibe Judith Butler, para referirse a los «guiones culturales» (58) propuestos por Castellanos y que son producto mayoritariamente de fuerzas coactivas heteronormativas dictadas por varones, pero con una dosis importante de aceptación-validación por parte de la mujer.

3. Yanina Ávila señala a Hermila Galindo como la primera mujer que desempeñó un cargo de representatividad diplomática, en el gobierno de Venustiano Carranza (93).

Feminismo/s 36, December 2020, 231-253 
Quitémosle, por ejemplo, la aureola al padre severo e intransigente y el pedestal a la madre dulce y tímida que se ofrece cada mañana para la ceremonia de la degollación propiciatoria. Los dos son personajes de una comedia ya irrepresentable y además han olvidado sus diálogos y los sustituyen por parlamentos sin sentido. Sus actitudes son absurdas porque el contexto en que surgieron se ha transformado y la gesticulación se produce en el vacío.

[...]

Quitémosle al vestido blanco y a la corona de azahares ese nimbo glorioso que los circunda. Son símbolos de algo muy tangible y que deberíamos de conocer muy bien, puesto que tiene su alojamiento en nuestro cuerpo: la virginidad. ¿Por qué la preservamos y cómo? ¿Interviene en ello una elección libre o es sólo para seguir la corriente de opinión? Tengamos el valor de decir que somos vírgenes porque se nos da la real gana, porque así nos conviene para fines ulteriores o porque no hemos encontrado la manera de dejar de serlo. O que no lo somos porque así lo decidimos y contamos con una colaboración adecuada. (Mujer que sabe latín... 39-40)

Sobre la maternidad, en su primer libro de 1950, escribió que era «el modo de perpetuación mucho más simple [...] que el de las creaciones culturales [del varón]. [...] La mujer, en vez de escribir libros, de investigar verdades, de hacer estatuas, tiene hijos.» (Sobre cultura femenina 181). Una aseveración que nos parece difícil de sostener, incómoda por decirlo suavemente, porque acá no está siendo crítica; en ese momento la escritora sí consideraba la procreación una facultad creativa de la mujer en términos meramente naturales o biológicos. Esta idea fue reelaborada en los setenta hasta convertirla en el dictum «La maternidad no es, de ninguna manera, la vía rápida para la santificación.» (Mujer que sabe latín... 40), el matiz introducido es importantísimo: el tener un hijo sigue siendo un hecho biológico, sí, pero que puede realizarse a voluntad. El ejercicio de la voluntad es la novedad. El cambio de enfoque es enorme. Acá, ya ha repensado sus tesis de años atrás, y entre otras lecturas es posible ver cómo corre subterráneamente lo que Beauvoir planteaba en su revisión de la fisiología femenina. En El segundo sexo la filósofa francesa niega que la condición de existencia necesaria de la mujer, su ser como sujeto de conciencia, esté determinado por la genitalidad y la capacidad de embarazo, nos advierte que eso es lo que nos han querido hacer creer en el discurso dominante. Mensualmente la mujer siente «su cuerpo como una cosa opaca y enajenada; ese cuerpo es presa de una vida terca y extraña que [...] hace y deshace en su interior una cuna; cada mes, un niño se dispone a nacer y aborta

Feminismo/s 36, December 2020, 231-253 
en el derrumbamiento de los rojos encajes; la mujer, como el hombre, es su cuerpo» (40), pero en el caso femenino, como construcción social, se vive una alienación o enajenación del cuerpo. El cuerpo, en este orden social, se intenta valorar sólo en su funcionalidad de sostenedor de la especie, por encima de la conciencia de ser sujeto. En el poema «Se habla de Gabriel» la Castellanos pondrá una experiencia del embarazo que puede leerse en ese mismo tenor:

Fea, enferma, aburrida,

lo sentía crecer a mis expensas,

robarle su color a mi sangre, añadir

un peso y un volumen clandestinos

a mi modo de estar sobre la tierra. (Poesía no eres tú 300)

La escritora mexicana califica al embarazo de «proceso fascinante y asqueroso» (Mujer que sabe latín... 23) y el hijo viene a ser «un simple vehículo para la perpetuación de la especie» (23). A este respecto, en uno de sus primeros poemarios, De la vigilia estéril (1950), habla del goce sensual de los cuerpos acoplados en el acto sexual; luego, de la germinación en el vientre y la espera gozosa del hijo; después, de la muerte de este que se malogra, para finalmente escogerse la mujer a sí misma, no como madre fallida o trunca sino como mujer renacida: "Sobre el cadáver de una mujer estoy creciendo» (Poesía no eres tú 39). Lo curioso es que esto también lo escribía más o menos por la misma época que su tesis donde defiende el tema de la perpetuación en la maternidad. Contradicción a veces necesaria en el proceso de desarrollo del pensamiento.

En su poemario de madurez En la tierra de en medio, apuntala la misma constante de indagar sobre ese constructo ideológico y social de la mujer filtrado por la mirada y la voluntad masculinas. Ya se anotaba líneas arriba cómo abre este libro el poema titulado «Bella dama sin piedad», en el cual se alude a una «presencia prometida», a alguien que se adivina por su huella, que se figura por su rastro; un ser vaporoso y ligero, asociado a la nube, al viento; es decir, la reelaboración del antiguo tópico de la muerte con forma de lo femenino; y que, no obstante, a lo largo del poemario va adquiriendo nuevas interpretaciones combinándose poco a poco con las actitudes que presenta la mujer frente a sus diversas circunstancias. Y entonces esa muerte ancestral es la Malinche, es la aniquilación entre los que fueron amantes, es el desamor, y su propia imagen en un autorretrato, deconstruyendo sin piedad ese territorio de en medio que aparentemente no tiene confines y que habita la mujer.

Feminismo/s 36, December 2020, 231-253 
En este poemario hay algunos momentos referidos al asunto. Porque lo que está en medio también puede hacer alusión a lo indefinido, «el lugar de la falta de ubicación» (Mujer que sabe latín... 37), un no-lugar, o un lugar que no se ha afianzado radicalmente, que no significa en su raíz. Una oquedad o la sensación de que no se ha cumplido algo. En «Pequeña crónica» el hijo es producto, entre otras cosas, de la menstruación (biología es destino): «La hemorragia mensual o sea en la que un niño / dice que sí, dice que no a la vida.» (Poesía no eres tú 291), la noción de hijo es apenas una posibilidad, algo que habita el nepantla: el ser y el no ser. En «Autorretrato» dice:

Soy madre de Gabriel: ya usted sabe, ese niño

que un día se erigirá en juez inapelable

y que acaso, además, ejerza de verdugo.

Mientras tanto lo amo. (Poesía no eres tú 298)

Aquí el hijo ya nació, ya es una realidad; pero la voz que es madre se aleja de aquella máscara de la normalidad maternal como idea preconcebida para convertirse en una voz crítica que ama sin la nublazón del juicio. La «retórica sacrificial» (Ávila 68) está siendo puesta en tela de juicio mediante el recurso de la ironía que Castellanos ha hecho suyo por lo menos desde Álbum de familia (1971). De nueva cuenta citamos otros versos de «Se habla de Gabriel» donde se registra el tono desmitificador de la exaltación maternalista:

Como todos los huéspedes mi hijo me estorbaba

ocupando un lugar que era mi lugar,

existiendo a deshora,

haciéndome partir en dos cada bocado.

[...]

Su cuerpo me pidió nacer, cederle el paso,

darle un sitio en el mundo,

la provisión de tiempo necesaria a su historia.

Consentí. Y por la herida en que partió, por esa

hemorragia de su desprendimiento

se fue también lo último que tuve

de soledad, de yo mirando tras de un vidrio.

Quedé abierta, ofrecida

a las visitaciones, al viento, a la presencia. (Poesía no eres tú 300) 
Lo evidente en este poema sin vueltas o escondites de la escritura es presentar lisa y llanamente cómo un hijo trastorna la existencia cotidiana de la mujer. Desde el primer verso se anuncia como un huésped, lo que ya de entrada le otorga un carácter de transitoriedad. Un huésped puede ser un habitante de una morada, en cuyo caso se hablaría de algo más íntimo y compenetrado con el espacio que le envuelve, su casa. Pero el huésped del poema de Castellanos calza mejor en la categoría de visitante, que además introduce una sensación de intromisión a un espacio que no es el suyo. Molesta el ritmo y los rituales de la madre que pasa a ser anfitriona de ese otro que crece en su cuerpo y se alimenta de su sangre hasta que nace al mundo mediante una «herida» literal, fisiológica del cuerpo, pero que de inmediato se torna simbólica: en un principio el hijo era algo que crecía en la entraña un poco a su aire, con vida propia, ajeno, y al final del poema, una vez nacido, ha trastocado lo mero fisiológico para entrar en lo emotivo-intelectual. La anfitriona deja de ser tal y se convierte en un ser puesto a merced de lo «abierto». La oclusión o cerramiento de espíritu que notamos en casi todo el poema, en los dos versos finales opera un cambio brusco, un volantazo en la dirección, y parece que entonces la mujer se permite el dominio de la apertura a otra experiencia de sensorialidad y de percepción del mundo. Gabriel fue el anunciador y provocador de ese nuevo mundo, y no creemos que esté de más remarcar el nombre propio con la obligada referencia al arcángel de la anunciación de la sagrada concepción. La maternidad acá, entonces, no es el extremo de la máscara cursi, ni del deber moral, ni del estereotipo social; se ha hecho añicos la imagen trillada de la abnegación, pero tampoco es el otro extremo del malditismo impersonal y violento de la desobligación o el maltrato. Es una especie de conciencia que encuentra el equilibrio entre el sentimiento y la razón. El descubrimiento de que la maternidad no necesariamente significa castración o mutilación, y podría resultar hasta germinal. Tal vez acá se empareje este resultado con la idea explorada en su tesis del 50 en el sentido de que la maternidad puede parangonarse al trabajo creativo: el genio da a luz su obra, lo mismo que la mujer da a luz al hijo. La idea es un parto de la intelección. Y lo mejor: se hace patente por medio del trabajo ensayístico y poético.

Y por el lado de las máscaras del lenguaje, Castellanos siempre defendió a la palabra porque un día descubrió que «si es exacta es letal / como lo es un guante envenenado» (Poesía no eres tú 302), así lo anota en el poema

Feminismo/s 36, December 2020, 231-253 
«Entrevista de prensa». Este poemario en varias partes destila decepción, pena, ira filtrada en versos irónicos, mordaces, que se ríen de uno mismo y su condición mortal de anhelos tan patéticos casi siempre. Por ejemplo, la desorientación, el desasosiego, la depresión juegan una mala pasada y hay que aferrarse a un ansiolítico poderoso que mitigue los latigazos del mundo cotidiano, este orden que va más allá de la mera voluntad del individuo porque corresponde a una serie de estructuras y relaciones históricas que se han heredado. Se lee en «Valium 10»:

A veces (y no trates

de restarle importancia

diciendo que no ocurre con frecuencia)

se te quiebra la vara con que mides,

se te extravía la brújula

y ya no entiendes nada.

El día se convierte en una sucesión

de hechos incoherentes, de funciones

que vas desempeñando por inercia y por hábito.

Y lo vives. Y dictas el oficio

a quienes corresponde. $\mathrm{Y}$ das la clase

lo mismo a los alumnos inscritos que al oyente.

$\mathrm{Y}$ en la noche redactas el texto que la imprenta

devorará mañana.

Y vigilas (oh, sólo por encima)

la marcha de la casa, la perfecta

coordinación de múltiples programas

-porque el hijo mayor ya viste de etiqueta

para ir de chambelán a un baile de quince años

y el menor quiere ser futbolista y el de en medio

tiene un póster del Che junto a su tocadiscos-.

Y repasas las cuentas del gasto y reflexionas, junto a la cocinera, sobre el costo

de la vida y el ars magna combinatoria

del que surge el menú posible y cotidiano. (305-306)

Máscaras todas que se nos han impuesto y cuyo desmonte ha ido constituyendo una tarea monumental en la que se va trabajando. Encontrar el equilibrio entre sentimiento y razón, saber quiénes somos, erradicar de nuestra experiencia castraciones y mutilaciones, derrumbar mitos o tal vez 
construirnos nuevos, iluminar el camino personal y con ello el colectivo, de eso y por eso escribió Castellanos. En eso continuamos: abriendo las cerradas galerías.

La muerte en varias modalidades simbólicas, La belle dame sans merci que se deslizaba por cerradas galerías en aquel primer poema, por aquellas que apresan y enmascaran, puede también y a contrapelo hacernos ver de frente nuestro verdadero rostro; podemos entrever esa posibilidad de dar muerte a los rostros falsos e intentar elegir una propia y sustancial imagen co-construida con un entorno nuevo. Si seguimos a la ensayista y poeta, en ese mundo emergente las palabras renacidas tendrían un papel medular: desbaratar las nocivas prácticas culturales que se han investido de tradiciones monolíticas, inclinando la balanza hacia un orden más racional y equilibrado.

\section{REFERENCIAS BIBLIOGRÁFICAS}

Althusser, Louis. Política e historia. De Maquiavelo a Marx. Cursos en la Escuela Normal Superior 1955-1972. Trad. Sandra Garzonio. Buenos Aires: Katz Editores, 2007.

Aristóteles. Poética. Magna Moralia. Intr., trad. y notas Teresa Martínez Manzano y Leonardo Rodríguez Duplá. Madrid: Gredos, 2011.

Ávila González, Yanina. «Las mujeres frente a los espejos de la maternidad». La Ventana 20 (2004): 55-100.

Castellanos, Rosario. Mujer que sabe latín... México: Fondo de Cultura Económica, 1984.

Castellanos, Rosario. Meditación en el umbral. Antología poética. Pról. Elena Poniatowska. México: Fondo de Cultura Económica, 1985.

Castellanos, Rosario. Sobre cultura femenina. Pról. Gabriela Cano. México: Fondo de Cultura Económica, 2005.

Castellanos, Rosario. Obras II. Poesía, teatro y ensayo. México: Fondo de Cultura Económica, 2016.

Castellanos, Rosario. Poesía no eres tú. México: Fondo de Cultura Económica, 2017.

De Beauvoir, Simone. El segundo sexo. México: DeBolsillo, 2016.

Kierkegaard, Soren. O lo uno o lo otro. Un fragmento de vida II. Trad. Darío González. Madrid: Trotta, 2007. 
Lamas, Marta. «Rosario Castellanos, feminista a partir de sus propias palabras». LiminaR. Estudios Sociales y Humanísticos 2 (2017): 35-47.

Persino, María Silvina. «La representación de la maternidad en la obra de Rosario Castellanos y Elena Garro». Revista de la Universidad de México 593-594 (2000): 9-14.

Platón. Diálogos. T. I. Trad. y notas J. Calonge Ruiz, Emilio Lledó, Carlos García Gual. Madrid: Gredos, 1985.

Schwob, Marcel. El terror y la piedad. Trad. Iair Kon. Buenos Aires: Libros del zorzal, 2006.

Virgilio. Virgilio en verso castellano. Bucólicas. Geórgicas. Eneida. Trad. Aurelio Espinoza Pólit. México: Editorial Jus, 1961.

Zaldívar Ovalle, María Inés. «Escritura y maternidad en un poemario de Rosario Castellanos». Literatura y lingüística 31 (2015): 13-30.

Zambrano, María. «Para una historia de la Piedad». Aurora: Papeles del Seminario de María Zambrano s/n (2012): 64-70. 